\title{
Blood transfusion and haemostatic management in the perioperative period
}

\begin{abstract}
Although legend would have us believe Pope Innocent VIII received the first blood transfusion in 1492, fact supports the first animal-to-animal transfusion in 1666 by Richard Lower, the first animal-to-human transfusion in 1667 by Jean Baptiste Denis, and the first human-tohuman transfusion in 1818 by James Blundell. Even in those early days, both the benefits and risks associated with transfusing blood products were recognized. In Canada, close to one million units of red blood cells are transfused annually. Two-thirds of blood transfusions are given in the perioperative period and more than half of all transfusions are administered by anaesthetists.

Recent concern about disease transmission associated with blood product transfusion has heightened interest in transfusion medicine. The more than 25 different blood products available are an essential component of modern medical care and, as members of the transfusion team, anaesthetists must be aware of the indications for, benefits and risks of, and alternatives to blood product administration. ${ }^{1-4}$
\end{abstract}

\section{Risks of transfusion}

I will comment on some of the transfusion risks outlined in the Table.

Most blood products are stored cold and deteriorate or lose efficacy rapidly when warmed. Platelet concentrates are an exception. The major concern with warmed blood is the increased risk for incubating bacteria. Iserson ${ }^{5}$ has reviewed blood warming in detail. For elective two-unit red cell transfusion over two to four hours, it is not necessary or possibly even desirable to warm the blood. In the case of rapid massive transfusion, and in infants, blood should be warmed prior to transfusion to avoid the detrimental effects of hypothermia.

To avoid embolising particulate matter, cellular blood products and plasma products should be administered through a filter not greater than $170 \mu$. Even platelets can be administered through an $80 \mu$ filter. Specialized filters are available to give leukocyte-poor blood when indicated. The routine use of $20-40 \mu$ filters does not appear to be clinically justified.

The biochemical changes which occur during transfu- sion are variable and unpredictable. It is suggested that $\mathrm{pH}$, $\mathrm{K}^{+}$and $\mathrm{Ca}^{++}$be monitored frequently during massive transfusion and clinically important abnormalities treated.

Much of the renewed interest in transfusion medicine and alternatives to transfusion stems from the transmission of the human immunodeficiency virus (HIV) and the subsequent development of acquired immunodeficiency syndrome (AIDS) in the recipient. In spite of testing all donor blood for HIV-1, there remains a risk of transmission of HIV from a seronegative donor ${ }^{6,7}$ because of a latency for seroconversion of at least six weeks. The estimated risk varies with the donor population. In Canada, one in one million has been quoted whereas in the U.S. one in 40,000 to one in 100,000 is a more likely figure.

The human T-cell lymphotrophic virus types I and II which cause adult T-cell leukemia and myelopathies is less common in North America (endemic in Japan) and donor blood is tested for anti-HTLV-1.

Hepatitis $A(H A V)$ can be transmitted by blood but is usually a mild disease and there is no carrier state. Hepatitis $B(H B V)$ is a more serious problem. The risk of infection per unit transfused is $1: 200-300$. Twenty-five percent of those infected will become jaundiced acutely, and $10 \%$ will become chronic carriers of which one quarter develop chronic active hepatitis. Delta hepatitis virus (HDV) which cannot infect on its own, can co-infect with HBV and cause fulminant hepatitis. Hepatitis $C(H C V)$ accounts for about half of the non $A$, non $B$ hepatitis post-transfusion. The risk for $\mathrm{HCV}$ is about 1:50-100 per unit transfused. Patients are usually asymptomatic and anicteric, but more than $50 \%$ will develop chronic hepatic disease with elevation of liver enzymes. In spite of recent testing for $\mathrm{HCV}$, the latency for seroconversion of infected patients is such that disease transmission may still be significant.

Cytomegalovirus infection is transmitted by blood transfusion (in leukocytes in the blood product) from seropositive donors to seronegative recipients. The immunocompromised recipient such as an organ transplant recipient may be at increased risk for morbidity and

From the Department of Anaesthesia, Victoria General Hospital, Halifax, Nova Scotia. 
TABLE Risks of transfusion

$$
\begin{aligned}
& \text { Physical } \\
& \text { - vascular access } \\
& \text { - volume } \\
& \text { - temperature } \\
& \text { - embolic } \\
& \text { - particulate } \\
& \text { - air }
\end{aligned}
$$

\section{Biochemical}

- acid-base disturbance

- potassium (hyperkalaemia)

- citrate toxicity/hypocalcaemia

- decreased 2,3 diphosphoglycerate

$$
\begin{aligned}
& \text { Disease transmission } \\
& \text { - Viral } \\
& \text { - human immunodeficiency virus } 1,2 \\
& \text { - human T-cell lymphotrophic virus I, II } \\
& \text { - hepatitis A, B, non A, non B, (C), D } \\
& \text { - Epstein-Barr vinus } \\
& \text { - cytomegalic virus } \\
& \text { - Bacterial } \\
& \text { - Spirochetes } \\
& \text { - Parasites (malaria) } \\
& \text { - Fungal } \\
& \text { Coagulopathy } \\
& \text { - Dilutional } \\
& \text { - platelets } \\
& \text { - factors } \\
& \text { - Disseminated intravascular coagulation } \\
& \text { - acute haemolytic reaction } \\
& \text { - associated with massive transfusion } \\
& \text { Immunological } \\
& \text { - Haemolytic } \\
& \text { - early } \\
& \text { - late } \\
& \text { - Nonhaemolytic } \\
& \text { - allergic } \\
& \text { - febrile } \\
& \text { - immunization } \\
& \text { - immunosuppression } \\
& \text { - graft vs host reaction } \\
& \text { - }
\end{aligned}
$$

mortality. ${ }^{8}$ In general, seronegative recipients of seronegative organ transplants should receive seronegative (or equivalent, i.e., leukocyte filtered) blood. Seronegative recipients of seropositive organs are given CMV hyperimmune globulin and there appears to be no added advantage to using seronegative blood in this situation. ${ }^{9}$

The Canadian Red Cross Society Blood Transfusion Service reports a $0.3 \%$ positive bacterial culture rate in their surveillance of platelets and red cells. Platelets, being stored at room temperature, represent the higher risk. However, red cells stored at $4^{\circ} \mathrm{C}$ have been found contaminated with some unusual bacteria such as Yersinia enterocolitica, and Pseudomonas fluorescens. ${ }^{10} \mathrm{~A}$ septic shock presentation post-transfusion should alert one to this possibility.

Most deaths associated with blood transfusion result from donor-recipient incompatability due to "clerical errors" in the laboratory or in patient and unit identification. ${ }^{1}$ These usually involve $\mathrm{ABO}$ incompatibility or sensitized Rh patients.

The non-haemolytic complications may be early or late, mild or severe. Allergic reactions may be $\operatorname{IgE}$ or $\operatorname{IgA}$ mediated. Urticaria may be simply treated with antihistamines. A severe reaction may occur in patients with inherited absence of $\operatorname{IgA}$. Anti-IgA in the recipient reacts with IgA in the donor product to produce anaphylaxis. The Canadian Red Cross Society Blood Services maintains a registry of IgA-deficient donors to provide plasma products in such cases.

Febrile reactions may have several causes but most are due to alloantibodies reacting with donor white cells. Leukocyte-poor products should be considered in patients who have had severe febrile reactions uncontrolled by medication.

Immunosuppression may be caused by several cellular components or by viral contamination of blood. Although improved kidney transplant survival was noted in transfused patients, cyclosporin has a similar effect, at a lower risk. Also, increased tumour recurrence rates have been noted in colorectal cancer patients who were transfused, and there may be an increased risk of bacterial infection in patients receiving blood transfusions., ${ }^{2,3,12}$

Immune reactions may take several forms in the recipient of a transfusion. The formation of antibodies by the recipient against donor cells is well recognized and may make future crossmatching difficult. Transfused donor lymphocytes may remain active in the recipient and produce antibodies against recipient cells leading to haemolysis. This has been described in organ transplant patients. ${ }^{13}$ Graft versus host disease may occur in select immunocompromised patients receiving blood products containing mitotically active, immune competent lymphocytes. Irradiated blood products are indicated in susceptible recipients ${ }^{14}$ (patients receiving bone marrow transplantation, congenital immune deficiency syndromes, intrauterine transfusions, neonatal exchange transfusions, lymphoma and leukaemic patients during immunosuppression, and possibly premature neonates).

The message is clear: transfuse blood products only when indicated, transfuse what is indicated and in the quantity indicated.

The major indications for blood product transfusion include volume replacement (albumin), increased oxygen carrying capacity, correction of abnormalities in haemostasis, augmentation of host response to infection (granulocytes), and immune therapy (various immune globulins). 
The indications for blood products in the perioperative period will be discussed including a review of haemostatis and perioperative haemostatic defects. Finally, alternatives to blood product transfusion will be described.

\section{Oxygen-carrying capacity}

Other than albumin, blood products should not be transfused primarily for volume resuscitation. Red blood cells have replaced whole blood for transfusion when an increase in oxygen-carrying capacity of blood is indicated. The " $10 / 30$ " rule (haemoglobin $=10 \mathrm{~g} \cdot \mathrm{dl}^{-1}$ or haematocrit of $30 \%$ ) no longer applies to all patients. Oxygen delivery depends on the cardiovascular and pulmonary systems as well as on haemoglobin concentration. Under resting conditions global oxygen extraction is only $25 \%$ (the heart extracts about $60 \%$ of delivered oxygen and has less reserve).

With isovolaemic haemodilution several compensating mechanisms are available to maintain adequate tissue oxygenation. The reduction in viscosity associated with haemodilution results in improved flow in the microcirculation and in effective reduction in afterload on the left ventricle. Cardiac output increases by increasing stroke volume and heart rate in variable amounts depending upon the clinical situation. During anaesthesia increased stroke volume is usually the more important. ${ }^{15}$ Coronary blood flow increases out of proportion to the increased cardiac output. The normal heart compensates down to haematocrits of $10-15 \% .{ }^{16,17}$ However, patients with limited ventricular reserve, valvular disease, ventricular hypertrophy, or coronary artery disease may decompensate at higher haematocrit levels. ${ }^{18-20}$ Oxygen extraction may increase to $70 \%$ during maximum exercise but this too may be limited, especially in critically ill patients with sepsis and adult respiratory distress syndrome. ${ }^{21,22}$ Increased 2,3 diphosphoglyceratic with a rightward shift of the oxyhaemoglobin dissociation curve also helps to compensate for anaemia, but is less important than the increased cardiac output and $\mathrm{O}_{2}$ extraction.

Robertie and Gravlee ${ }^{4}$ have suggested guidelines for transfusion thresholds in the perioperative period:

1 Haemoglobin of $6 \mathrm{~g} \cdot \mathrm{dl}^{-1}$ for compensated chronic anaemic patients with starting haemoglobin $\leq 8 \mathrm{~g} \cdot \mathrm{dl}^{-1}$, healthy patients undergoing intentional intraoperative haemodilution, and patients undergoing hypothermic cardiopulmonary bypass.

2 Haemoglobin of $8 \mathrm{~g} \cdot \mathrm{dl}^{-1}$ as the minimum acceptable preop level for surgery in which more than $500 \mathrm{ml}$ of blood loss is anticipated, for postoperative cardiac surgery patients, intraoperatively for many ASA II and III patients.

3 Haemoglobin of $10 \mathrm{~g} \cdot \mathrm{dl}^{-1}$ for patients unlikely to increase cardiac output or regional blood flow suffi- ciently to compensate, postoperative patients with complications limiting cardiac reserve and increasing $\mathrm{O}_{2}$ demand, elderly ( $>65 \mathrm{yr}$ ), and most patients requiring prolonged ( $>48 \mathrm{hr}$ ) ventilatory support.

These are only guidelines and clinicians must individualize therapy. In general $7 \mathrm{~g} \cdot \mathrm{dl}^{-1}$ is replacing the 10 $\mathrm{g} \cdot \mathrm{dl}^{-1}$ rule for an acceptable preoperative haemoglobin concentration ${ }^{23-25}$ in the isovolaemic patient with otherwise stable cardiopulmonary systems.

\section{Haemostasis}

Understanding haemostasis will facilitate appropriate use of coagulation tests and choice of blood products in the perioperative period. The haemostatic system involves vascular, cellular and humoral components with complex positive and negative feedback controls resulting in rapid, well-localized response to vessel injury. Primary haemostasis vasoconstricts and forms the platelet plug; coagulation forms fibrin clot; fibrinolysis removes fibrin.

Vascular endothelial cells secrete prostacyclin, a vasodilator and inhibitor of platelet aggregation. Damaged endothelium exposes subendothelial collagen. Von Willebrand factor, secreted by endothelial cells and platelets, permits adhesion of circulating platelets to collagen. Activated platelets release thromboxane $A_{2}$ which causes local vasoconstriction and platelet release of adenosine diphosphate (ADP) which promotes platelet adhesion and aggregation and formation of the platelet plug at the site of vessel injury. Thromboxane $A_{2}$ and prostacyclin have opposing effects on the vessel and ADP, and this accounts for the localized haemostatic response.

The coagulation phase of haemostasis involves plasma protein clotting factors, calcium and phospholipid. The origin of the phospholipid determines which cascade (extrinsic or intrinsic) is followed. Phospholipid from outside the vessel lumen, tissue thromboplastin, is involved in the extrinsic system; phospholipid from platelets, platelet factor 3 , is required for the intrinsic pathway. This division is somewhat artificial as there are interactions between the two pathways to form fibrin. However, this interpretation of the coagulation cascade helps to conceptualize defects in the system and to interpret standard coagulation tests. The extrinsic system is faster than the intrinsic system. Tissue thromboplastin released into the circulation complexes with factor VII to activate factor X. Activation of factor $\mathrm{X}$ via the intrinsic system is more complex. Contact activation involving factor XII, factor XI, prekallikrein and high molecular weight kinogen initiate the process. Contact of factor XII with a negatively charged substance (collagen, endotoxin, glass, kaolin, etc.) is the first step. With high molecular weight kinogen as a co-factor, prekallikrein and factor XI bind to the surface generating activated factor XI (activated factors are designated with 
"a", e.g., XIa). Factor XIa cleaves IX to IXa which forms a complex on the platelet surface with factor VIIIa, calcium and phospholipid to activate factor $X$.

Factor Xa initiates the common pathway. Factor Xa forms a complex with factor $\mathrm{Va}$, calcium, and phospholipid cleaving prothrombin to form thrombin. Thrombin, bound to platelet factor 3 , cleaves fibrinogen to fibrin monomers which aggregate to form a soluble fibrin polymer (fibrin S). Factor XIII, activated by thrombin and calcium, promotes covalent bonding (crosslinking) of fibrin monomers to form a stable insoluble fibrin clot. Thrombin not only converts fibrinogen to fibrin and activates factor XIII, but also enhances activity of the cofactors V and VIII, and initiates fibrinolysis and further platelet aggregation.

Note that vitamin K-dependent factors (II, VII, IX, X) are involved in the extrinsic, intrinsic, and common pathways. Because factor VII has the shortest half-life, vitamin $\mathrm{K}$ deficiency, liver disease and warfarin therapy will initially affect the extrinsic system as reflected in an elevated prothrombin time.

Prevention of uncontrolled massive intravascular coagulation is accomplished by several mechanisms. As noted, prostacyclin from normal vascular endothelium maintains vasodilation, inhibits platelet aggregation and exposure of the phospholipid platelet factor 3. Normal blood flow dilutes and washes away activated coagulation factors which are preferentially removed from the circulation. Antithrombin III, protein $\mathrm{C}$ and protein $\mathrm{S}$ are naturally occurring anticoagulants. Antithrombin III complexes with thrombin and IXa, Xa, XIa and XIIa clearing them from the circulation. Heparin enhances the binding of antithrombin III 100 times. Protein C, the activation of which is enhanced by protein $\mathrm{S}$, degrades factors $\mathrm{Va}$ and VIIICa and promotes fibrinolysis. Fibrinolysis normally proceeds in a controlled fashion as well. When the danger of hemorrhage passes, the fibrin clot must be modified to reestablish blood flow in the vessel. Plasminogen is bound to fibrin within the clot and when activated by tissue plasminogen activator the resulting plasmin lyses the clot from within. Circulating antiplasmin neutralizes free plasmin. Plasmin cleaves fibrinogen, cross-linked and non cross-linked fibrin with resulting specific fibrin degradation products which can inhibit coagulation and platelet function.

\section{Screening tests for haemostasis}

The history and physical examination may require supplementation with a number of tests of the haemostatic mechanism. A normal platelet count is greater than $150,000 \cdot \mu \mathrm{l}^{-1}$. The test loses accuracy below $20,000 \cdot \mu \mathrm{l}^{-1}$. The bleeding time is normally less than $10 \mathrm{~min}$ and is a marker of platelet function at platelet counts greater than
$100,000 \cdot \mu \mathrm{l}^{-1}$ as it increases linearly at counts from $100,000 \cdot \mu l^{-1}$ to $10,000 \cdot \mu l^{-1}$. Decreased or abnormal Von Willebrand factor, severe hypofibrinoginaemia, and severe anaemia will prolong the bleeding time. ${ }^{26}$ The prothrombin time (PT) and partial thromboplastin time (PTT) are the traditionally used tests of the extrinsic and intrinsic coagulation cascades respectively. Note that these will remain normal, until the factor levels are less than $30 \%$ normal, that the common pathway is also assessed by these tests, and since the endpoint of these tests is fibrin clot formation, factor XIII is not assessed. A prolonged PTT, not corrected by a 50:50 mix of normal plasma, may be caused by inhibitors of coagulation factors and represent a more complex problem to handle than factor deficiency. The thrombin time is prolonged by heparin whereas the reptilase time is not. Both are prolonged by fibrinogen abnormalities and fibrin degradation products.

Rapaport ${ }^{27}$ proposed guidelines for preoperative screening by assigning patients to risk levels based on the bleeding history and proposed surgery. Patients in level I have a negative bleeding history, are scheduled for minor procedures, and no screening is recommended. Level II includes patients with negative bleeding histories undergoing major surgery. A platelet count and a PTT should be done. Level III patients have a history suggesting a bleeding disorder and also includes patients whose surgery places great demands on the haemostatic system, e.g., cardiopulmonary bypass, prostate surgery, or surgery in which little bleeding can be tolerated (neurosurgery). More extensive screening is indicated here including PT, PTT, platelet count, and possibly bleeding time and fibrinolysis testing. Level IV patients have a strongly positive bleeding history and may require, in addition to the screening tests noted, specific factor assays, platelet aggregometry, thrombin time, etc. A haematologist should be involved in complex cases.

\section{Common bleeding disorders in the perioperative period}

\section{Congenital}

The most common disorders are Von Willebrand's disease and haemophilia A and B. Von Willebrand factor is necessary for platelet adhesion and as a carrier for factor VIII. Von Willebrand's disease is classified as Types I, II-A, B, C, D, III, and platelet type vWD. Type I, the most common, has autosomal dominant inheritance. These patients can be safely prepared for surgery using 1-deamino-8-Darginine vasopressin (DDAVP) $0.3 \mu \mathrm{g} \cdot \mathrm{kg}^{-1} i v$, one hour preoperatively. Correction of the bleeding time and/or adequate elevation of factor VIII should be documented $45 \mathrm{~min}$ after the DDAVP which is then repeated daily until wound healing is complete. Types II and III will need 
cryoprecipitate in a dose of 2 bags $\cdot 10 \mathrm{~kg}^{-1}$ every $12 \mathrm{hr}$ starting one hour preoperatively and continuing until wound healing.

Haemophilia A and B are X-linked deficiencies of factors VIII and IX respectively affecting males. Preparation for surgery in haemophilia A requires elevation of factor VIII to $80-100 \%$ of the normal levels. One unit of factor VIII $\cdot \mathrm{kg}^{-1}$ raises plasma level by $2 \%$. Cryoprecipitate has about 100 units VIII per $10 \mathrm{ml}$ bag. Lyophilized factor VIII concentrate is also available with the activity on the label, appropriate for haemophilia A, but not for Von Willebrand's disease. Forty to fifty $\mathrm{U} \cdot \mathrm{kg}^{-1}$ one hour before surgery will raise factor VIII levels to $80-100 \%$ for surgery and $15-25 \mathrm{U} \cdot \mathrm{kg}^{-1}$ every $12 \mathrm{hr}$ for $10-14$ days will keep factor VIII activity around $30-50 \%$ postoperatively. In dental surgery epsilon amino caproic acid $1 \mathrm{~g}$ orally every four hours for 7-10 days is given as an antifibrinolytic. Mild haemophilia A may respond adequately to DDAVP given one hour pre-operatively and $\mathrm{ql} 2 \mathrm{~h}$ postoperatively with frequent monitoring of factor VIII.

In haemophilia $\mathrm{B}, 1$ unit $\mathrm{IX} \cdot \mathrm{kg}^{-1}$ raises plasma factor IX by $1 \%$. Factor IX complex, which contains other activated factors, has some risk of thrombosis associated with its use and some patients are placed on low-dose subcutaneous heparin prophylactically.

\section{Acquired}

Disorders of platelet number and function are very common. Decreased platelet count is the result of decreased production, increased consumption, destruction or sequestration and management will vary depending upon the aetiology. In general, increased surgical bleeding does not occur until the platelet count is less than 50,000 $100,000 \cdot \mu 1^{-1}$. Spontaneous bleeding may occur at levels below $20,000 \cdot \mu l^{-1}$. Acquired platelet function disorders are common, with aspirin causing the major concern. Aspirin affects platelet aggregation through inhibition of synthesis of thrombroxane $A_{2}$ and the defect lasts for the lifetime of those platelets ( 10 days). DDAVP may reverse some of the effect ${ }^{28}$ and two units of platelets should release enough ADP to aggregate the affected platelets. The bleeding time as a prediction of risk for increased bleeding has been criticized ${ }^{29}$ and results of studies on increased bleeding in surgical patients taking aspirin are conflicting. However, one should be aware of the added effects of platelet dysfunction in patients with other coagulopathies. The platelet abnormality in uraemia is not corrected by platelet transfusion but responds to dialysis and DDAVP. Correction of severe anaemia may hel ${ }^{26}$ as does cryoprecipitate ${ }^{30}$ in shortening the bleeding time in uraemia.

Coagulopathy in liver disease is multifactorial resulting from decreased platelet count secondary to decreased production, sequestration in the spleen, or consumpton in DIC, abnormal platelet function secondary to alcohol or fibrin degradation products, and decreased coagulation factors including fibrinogen, or abnormal fibrinogen. Disseminated intravascular coagulation (DIC) can occur in liver disease and is also a complication of peritoneovenous shunts for ascites control. Platelets, frozen plasma and cryoprecipitate may be needed in severe bleeding disorders. Vitamin K may be effective even in cases with significant hepatic dysfunction and there is some work suggesting DDAVP might shorten the bleeding time. ${ }^{28}$

Patients receiving Warfarin who require immediate surgery will require transfusion with frozen plasma along with Vitamin K therapy. Vitamin K will start reversing the defect in $4-6 \mathrm{hr}$ but will require much longer for full reversal and makes subsequent reanticoagulation difficult. Vitamin $\mathrm{K}$ deficiency from malnutrition and antibiotic therapy is common in hospitalized patients and should be considered in patients with an elevated prothrombin time on screening tests.

The massively transfused patient (receiving greater than one blood volume in $24 \mathrm{hr}$ or less) warrants special consideration. The associated coagulopathy is usually dilutional thrombocytopaenia but increased platelet consumption and destruction may contribute, as does decreased labile factors V and VIII in some cases, and hypofibrinogenaemia if DIC is part of the clinical picture. Although prophylactic transfusion of platelets, frozen plasma and cryoprecipitate in cardiac surgery and massively transfused patients is discouraged, ${ }^{31,32}$ one may have to use an educated guess in some situations as standard laboratory tests may not be rapidly available in the operating room. Thromboelastography may help to diagnose such intraoperative coagulopathies and guide therapy. ${ }^{33}$ Since severe anaemia may affect platelet function red cell transfusion is important not only for oxygen-carrying capacity in these patients.

\section{Alternatives to homologous blood transfusion}

In addition to accepting a lower haematocrit transfusion trigger there are several options to decrease homologous transfusion. ${ }^{34}$

Induced hypotension, although still somewhat controversial, has been shown to decrease surgical blood loss and if carefully performed in selected patients is safe. ${ }^{4}$ However, a decrease in blood pressure, not cardiac output, is desired if combined with moderate haemodilution. A $30 \%$ reduction in mean arterial pressure with a lower limit of 50 $\mathrm{mmHg}$ is considered safe.

Acute haemodilution, before or during surgery, to a haematocrit of $24 \%$ will result in a decreased haemoglobin loss and hopefully lower transfusion requirement. This can be accomplished by removing blood from the patient to be 
retransfused later in the case, or simply by vasodilatation and infusing crystalloid or colloid to reach a predetermined haematocrit. Since diuresis may be necessary, renal function should be adequate and serial haematocrits followed closely.

Predonated autologous blood donation ${ }^{35}$ is underutilized and could be offered to some high-risk patients. ${ }^{36}$ However, the risk of volume overload, contamination and clerical errors leading to incompatibility are still present, and if a patient who has predonated doesn't need to be transfused, he or she should not be transfused. ${ }^{37}$ Preoperative treatment with erythropoietin may increase the volume of red cells obtained preoperatively. ${ }^{38}$

Intraoperative blood salvage is used most successfully in operative procedures with large blood loss such as cardiovascular, orthopaedic, trauma and liver transplantation surgery. Relative contraindications include infection and malignancy. Presently, only red cells are salvaged but this may change. ${ }^{39}$

Pharmacological agents may decrease blood loss in some situations. ${ }^{28}$ DDAVP and vitamin $\mathrm{K}$ have been mentioned. Results with DDAVP in cardiac surgery have been conflicting and at present there seems little recommendation for its routine use in that setting. Antifibrinolytics (epsilon amino caproic acid, tranexamic acid) have decreased bleeding in oral surgery, prostate surgery and cardiac surgery, with no apparent increased risk of thrombosis. ${ }^{4.40}$ Aprotinin, a serine protease inhibitor, inhibiting plasmin and kallikrein and preserving platelet membrane receptors during cardiopulmonary bypass, has been shown to decrease blood loss during cardiac surgery. ${ }^{4,41,42}$

The blood substitutes, perfluorocarbons and polymerized haemoglobin, are still at the research level and are not readily available for clinical use.

\section{Summary}

A lower transfusion trigger, a better understanding of haemostasis, and an awareness of alternatives to homologous transfusion should make the practice of transfusion medicine more rational.

\section{References}

1 Canadian Red Cross blood transfusion service - clinical guide to transfusion products and practices, 1987.

2 Ramsey JG, Growe GH, Stehling L, Takaori M, Buskard $N A$, Ikeda $H$. Symposium report - blood and blood substitutes. Can J Anaesth 1991; 38: 595-612.

3 Benumof $J L$, Spiess BD. Hemorrhagic disorders. Anesthesiol Clin N Am 1990; 8: 441-629.

4 Gravlee GP, et al. Blood conservation. Int Anesthesiol Clin 1990; 28: 183-243.

5 Iserson $K V$, Huestis $D W$. Blood warming: current applications and techniques. Transfusion 1991; 31: 558-71.
6 Ward JW, Holmberg SD, Alien JR, et al. Transmission of human immunodeficiency virus (HIV) by blood transfusions screened as negative for HIV antibody. N Engl J Med 1988; 318: 473-8.

7 Menitoue JE. Current risks of transfusion - associated human immunodeficiency virus infection. Arch Pathol Lab Med 1990; 114: 330-4.

8 Hillyer $C D$, Snydman DR, Berkman EM. The risk of cytomegalovirus infection in solid organ and bone marrow transplant recipients: transfusion of blood products. Transfusion 1990; 30: 659-6.

9 Preiksaitis $J K$. Indications for the use of cytomegalovirus seronegative blood products. Transfusion Medicine Reviews 1991; 5: 1-17.

10 Goldman M, Blajchman MA. Blood product-associated bacterial sepsis. Transfusion Medicine Reviews 1991; 5: 73-83.

11 Myhre BA. Fatalities from blood transfusion. JAMA 1980; 244: 1333-5.

12 Council Report - introduction to the management of immunosuppression. JAMA 1987; 257: 1781-5.

13 Nusbacher $J$. Blood transfusion support in liver transplantation. Transfusion Medicine Reviews 199; 15: 207-13.

14 Leitman SF, Holland PV. Irradiation of blood products indications and guidelines. Transfusion 1985; 25 : 293-303.

15 Laks H, Piton RN, Klovekorn WP, et al. Acute hemodilution: its effect on hemodynamics and oxygen transport in anesthetized man. Ann Surg 1974; 180: 103-9.

16 Wilkerson $D K$, Rosen $A L$, Sehgal LR, et al. Limits of cardiac compensation in aneınic baboons. Surgery 1988; 103: 665-70.

17 Levine E, Rosen A, Sehgal L, et al. Physiologic effects of acute anemia: implications for a reduced trigger finger. Transfusion 1990; 30: 11-4.

18 Kalayashi H, Estafanous FG, Fauad FM. Effects of myocardial infarction on hemodynamic responses to variable degrees of hemodilution. Anesth Analg 1988; 67: S117.

19 Estafanous FG, Selim Tarayi RC. Effects of cardiac depression on hemodynamic responses to hemodilution. Anesthesiology 1985; 63: A38.

20 Rao TLK, El-Etr AA, Mortoya A. Hemodynamic changes due to normovolemic anemia in coronary disease patients. Anesthesiology 1979; 51: S164.

21 Weg JG. Oxygen transport in adult respiratory distress syndrome and other acute circulatory problems: relationship of oxygen delivery and oxygen consumption. Crit Care Med 1991; 19: 650-7.

22 Czer LSC, Shoemaker WC. Optimal hematocrit value in critically ill postoperative patients. Surg Gynecol Obstet 1978; 147: 363-8.

23 Stehling $L$, Zauder HL. How low can we go? Is there a way to know? Transfusion 1990; 30: 1-3. 
24 Consensus conference - perioperative red blood cell transfusion. JAMA 1988; 260: 2700-3.

25 Goodnough LT, Johnston MFM, Ramsey G, et al. Guidelines for transfusion support in patients undergoing coronary artery bypass surgery. Ann Thorac Surg 1990; 50: 675-83.

26 Sixma JJ. Estimation of the bleeding time. In: Hoffman R, Benz EJ, Shattie SJ, Furie B, Cohen HJ (Eds.). Hematology Basic Principles and Practice, New York: Churchill Livingstone Inc., 1991; 1810-5.

27 Rapaport SI. Preoperative hemostasis evaluation: Which tests, if any? Blood 1983; 61: 229-31.

28 Bolan $C D$, Alving BM. Pharmacologic agents in the management of bleeding disorders. Transfusion 1990; 30: 541-51.

29 Lind SE. The bleeding time does not predict surgical bleeding. Blood 1991; 77: 2547-52.

30 Janson PA, Juhelirer SJ, Weinstein $M$, et al. Treatment of the bleeding tendency in uremia with cryoprecipitate. $\mathrm{N}$ Engl J Med 1980; 303: 318.

31 Consensus conference - platelet transfusion therapy. JAMA 1987; 257: 1777-80.

32 Consensus conference - fresh-frozen plasma. Indications and risks. JAMA 1985; 253: 551-7.

33 Tuman KJ, Spiess BD, McCarthy RJ, Ivankovich $A D$. Effects of progressive blood loss on coagulation as measured by thromboelastography. Anesth Analg 1987; 66: 856-63.

34 Spence RK. The status of bloodless surgery. Transfusion Medicine Reviews 1991; 5: 274-86.

35 Chambers LA, Kruskall MS. Preoperative autologous blood donation. Transfusion Medicine Reviews 1990; 4: $35-46$.

36 Mann $M$, Sacks $H J$, Goldfinger $D$. Safety of autologous blood donation prior to elective surgery for a variety of potentially "high-risk" patients. Transfusion 1983; 23: 229-32.

37 Miller AC, Scherba-Krugliak L, Toy PT, Drasner $K$. Hypotension during transfusion of autologous blood. Anesthesiology 1991; 74: 624-8.

38 Goodnough LT, Rudnick S, Price TH, et al. Increased preoperative collection of autologous blood with recombriant human erythropoietin therapy. N Engl J Med 1989; 321: 1163-8.

39 Pineda $A A$, Valbonesi $M$. Intraoperative blood salvage. In: Contreras M (Ed.) Bailliere's Clinical Haematology 1990; 3: 385-403.

40 Horrow JC, Hlavacek J, Strong MD, et al. Prophylactic tranexamic acid decreases bleeding after cardiac operations. J Thorac Cardiovasc Surg 1990; 99: 70-4.
41 Bidstrup BP, Royston D, Sapsford RN, Taylor $K M$. Reduction in blood loss and blood use after cardiopulmonary bypass with high dose aprotinin (Trasylol). Thorac Cardiovasc Surg 1989; 97: 364-72.

42 Dietrich $W$, Spannagl $M$, Jochum $M$, et al. Influence of high dose aprotinin treatment on blood loss and coagulation patterns in patients undergoing myocardial revascularization. Anesthesiology 1990; 73: 1119-26. 


\section{Transfusion sanguine et contrôle de l'hémostase dans la période périopératoire}

Même si la légende voudrait nous faire croire que le Pape Innocent VIII a reçu la première transfusion sanguine en 1492 , on rapporte en fait la première transfusion d'animal à animal en 1666 par Richard Lower, la première transfusion d'un animal à un homme en 1667 par Jean Baptiste Denis et la première transfusion entre personnes en 1818 par James Blundell. Même à cette époque, on a reconnu autant les bénéfices que les risques inhérents à la transfusion de produits sanguins. Au Canada, près d'un million d'unités de globules rouges sont transfusées annuellement. Les $2 / 3$ des transfusions sont données dans la période périopératoire et plus de la moitié de toutes les transfusions sont administrées par des anesthésistes.

L'inquiétude récente à propos de la transmission de maladies par les produits sanguins a accru l'intérêt dans la médecine de transfusion. Il y a plus de 25 produits sanguins différents disponibles, composantes essentielles des soins médicaux modernes, et comme membres de l'équipe de transfusion, les anesthésistes doivent être au courant des indications, des risques et bénéfices, et des alternatives à la transfusion de produits sanguins. ${ }^{1-4}$

\section{Risques de transfusion}

Je vais faire quelques commentaires sur les risques reliés à la transfusion; ils sont soulignés dans la Tableau.

La plupart des produits sanguins sont entreposés au froid et se détériorent ou perdent leur efficacité rapidement lorsqu'ils sont réchauffés. Les concentrés de plaquettes sont une exception. L'inquiétude principale avec le sang réchauffé est l'augmentation du risque d'incubation bactérienne. Iserson ${ }^{5}$ a revu le réchauffement du sang en détail. Lorsqu'il s'agit de donner deux unités de globules rouges en deux à quatre heures, il n'est pas nécessaire ou même désirable de réchauffer le sang; en cas de transfusions massives données rapidement, et chez les nouveau-nés, le sang devra être réchauffé avant la transfusion pour éviter les effets néfastes de l'hypothermie.

Pour empêcher l'embolisation d'agrégats, les produits cellulaires sanguins et plasmatiques devraientêtre administrés à travers un filtre à pores de dimension inférieure à $170 \mu$. Même les plaquettes peuvent être administrées à travers un filtre de $80 \mu$. Des filtres spécialisés sont dispo- nibles pour donner du sang pauvre en leucocytes lorsqu'il y a indication. L'utilisation courante de filtres de 20 à $40 \mu$ ne semblent pas être justifiée en clinique.

Les changements biochimiques qui se produisent pendant la transfusion sont variables et imprévisibles. On pense que le $\mathrm{pH}$, le potassium et la calcium devraient être évalués fréquemment pendant la transfusion massive et que les anomalies cliniquement importantes soient traitées.

Une grande partie de l'intérêt récent dans la transfusion et ses alternatives originent de la transfusion du virus d'immunodéficience humaine (HIV) et du développement subséquent du syndrome d'immunodéficience acquise (SIDA) chez le receveur. En dépit de la vérification de tout le sang de donneur pour le HIV-1, il y a un risque persistant de transmission du virus à partir de donneurs séronégatifs ${ }^{6.7}$ à cause d'un temps de latence de séroconversion d'au moins 6 semaines. Le risque varie avec la population de donneurs. Au Canada, on cite un risque de un pour un million alors qu' aux États-Unis le risque s'établit entre un pour 40000 et un pour 100000 .

Le virus humain lymphotrophique des cellules-T de type I et II, qui cause la leucémie adulte à cellules-T et les myélopathies, est moins courant en Amérique du Nord (endémique au Japon) et le sang des donneurs est vérifié pour l'anti-HTLV-1.

L'hépatite A peut être transmise par le sang mais est habituellement une maladie modérée et il n'y a pas de porteurs actifs. L'hépatite $B$ présente un problème plus sérieux. Le risque d'infection par unité transfusée est de l'ordre de 1:200 à 1:300. Vingt-cinq \% des personnes infectées présenteront de l'ictère aigu, $10 \%$ deviendront des porteurs chroniques et $2.5 \%$ développeront une hépatite chronique active. Le virus de l'hépatite delta ne peut infecter de lui-même, mais peut cependant produire une infection croisée avec le virus de l'hépatite $B$ et amener une hépatite fulminante. L'hépatite $C$ est responsable d'environ la moitié des hépatites post-transfusion à virus ni $\mathrm{A}$ ni $\mathrm{B}$. Le risque d'hépatite $\mathrm{C}$ est d'environ 1:50-100 par unité transfusée. Les patients sont habituellement asymptomatiques et anictériques, mais plus de 50\% vont voir apparaître une hépatite chronique active avec élévation d'enzymes hépatiques. En dépit du dépistage 
TABLEAU Risques de la transfusion

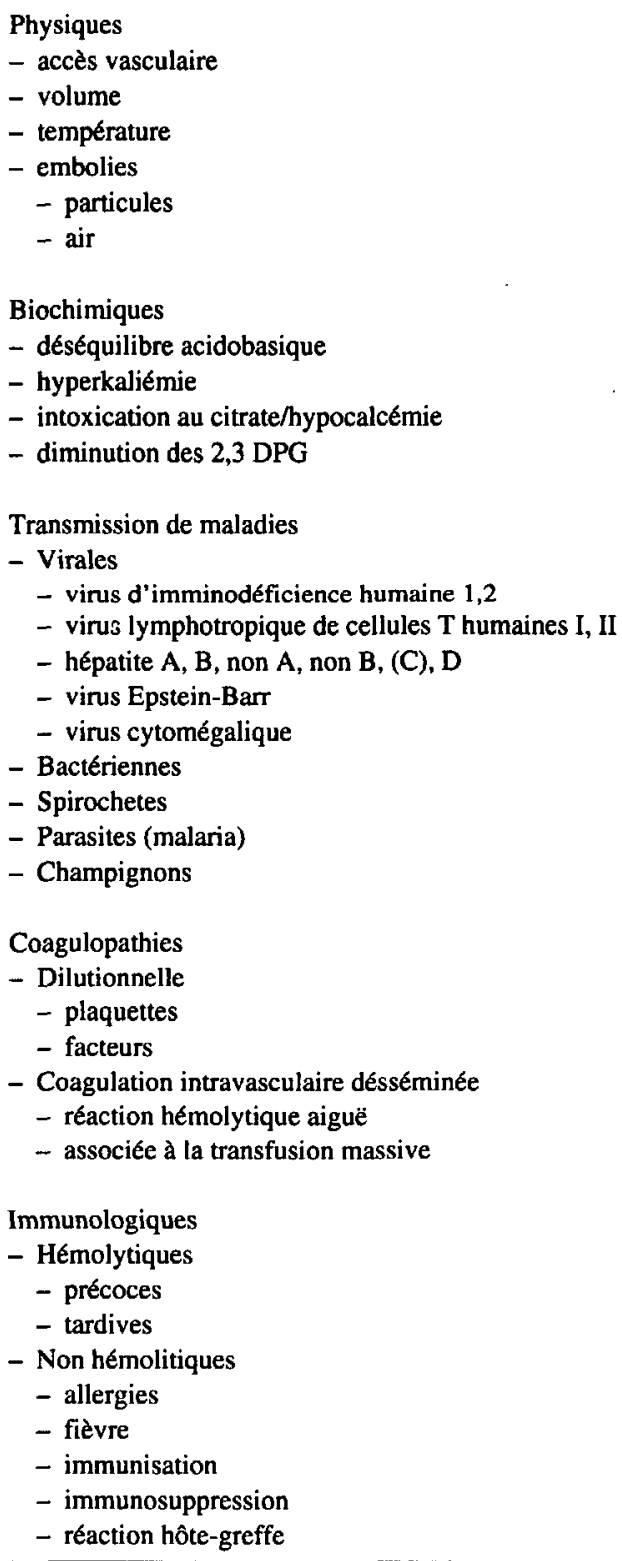

récent pour le virus de l'hépatite $\mathrm{C}$, le temps de latence pour la séroconversion des patients infectés est telle que la transmission de la maladie peut encore être significative.

L'infection à cytomégalovirus est transmise par transfusion sanguine (via les leucocytes) des donneurs séropositifs à ceux séronégatifs. Un receveur immunocompromis (e.g., receveur d'organe) peut être à risque accru de morbidité et de mortalité. ${ }^{8}$ En général, les receveurs séronégatifs d'organes transplantés séronégatifs devraient recevoir du sang séronégatif (ou équivalent, i.e., avec filtration de leucocytes). Les receveurs séronégatifs d'organes séropositifs reçoivent de la globuline hyperim- mune et il ne semble pas qu'il y ait d'avantages à l'utilisation du sang séronégatif dans cette situation."

Le service de transfusion de la Société Canadienne de la Croix Rouge rapporte un taux de $0,3 \%$ de cultures bactériennes positives dans leur surveillance de contenants de plaquettes et de globules rouges. Les plaquettes, puisqu'elles sont entreposées à température de la pièce, offrent un risque plus élevé. Cependant, les globules rouges entreposés à $4^{\circ} \mathrm{C}$ se retrouvent à l'occasion contaminées avec des bactéries inhabituelles telles le Yersinia enterocolitica, et le Pseudomanas fluorescens. ${ }^{10}$ Un choc septique consécutif à une transfusion devrait suggérer cette possibilité.

La plupart des décès associés à la transfusion sanguine proviennent d'incompatibilité entre donneur et receveur à cause d'erreurs cléricales dans le laboratoire ou dans l'identification des patients et des unités de sang. ${ }^{\text {" }}$ Ces décès impliquent habituellement une incompatibilité ABO ou Rh.

Les complications non-hémolytiques peuvent être précoces ou tardives, bénignes ou sévères. Les réactions allergiques peuvent être médiées par les IgE ou les IgA. L'urticaire sera traitée simplement par anti-histaminiques. Une réaction importante peut survenir chez des patients avec absence congénitale d'IgA. Les anti-IgA chez le receveur réagissent avec les IgA du donneur pour produire l'anaphylaxie. Les services de la Société Canadienne de la Croix Rouge conservent un registre des donneurs déficients en IgA pour assurer l'approvisionnement de produits plasmatiques dans de telles situations.

Les réactions fébriles peuvent avoir plusieurs causes mais la plupart sont dues à des alloanticorps réagissant avec les globules blancs du donneur. L'on devrait penser donner des produits pauvres en leucocytes aux patients qui ont eu des réactions fébriles sévères mal contrôlées par la médication.

L'immunosupression peut être produite par plusieurs composantes cellulaires ou une contamination virale $\mathrm{du}$ sang. Même si l'on note chez les patients transfusés une meilleure survie de leur greffe rénale, la cyclosporine a un effet similaire, à un risque moindre. De plus on note une augmentation de la récurrence de tumeurs chez les patients porteurs de cancer colo-rectal qui ont été transfusés, et on pense même qu'il y a un risque plus élevé d'infections bactériennes chez les patients qui reçoivent des transfusions. ${ }^{2,3,12}$

Les réactions immunitaires peuvent se présenter sous plusieurs formes chez les receveurs de transfusions. La formation d'anticorps contre les cellules de donneur par le receveur est un phénomène bien connu et qui peut rendre le croisement sanguin ultérieur difficile. Les lymphocytes du donneur peuvent demeurer actifs chez le receveur et produire des anticorps contre les cellules de ce dernier, ce 
qui amène de l'hémolyse. On a décrit ce phénomène chez les receveurs d'organes. ${ }^{13}$ Les problèmes de rejet peuvent se produire chez certains patients immunocompromis qui reçoivent des produits sanguins contenant des lymphocytes immunocompétents et à division active. Les produits sanguins irradiés sont indiqués chez les receveurs vulnérables $^{14}$ (patients qui reçoivent des transplantations de moëlle, les syndromes congénitaux de déficiences immunitaires, les transfusions intra-utérines, l'exsanguinotransfusion, les porteurs de lymphomes et de leucémies pendant leur immunosupression, et possiblement les nouveau-nés prématurés).

Le message est clair: transfusez les produits sanguins seulement s'il y a indication, donnez ce qui est nécessaire et seulement dans la quantité indiquée par la situation.

Les indications les plus importantes pour les produits de transfusion comprennent le remplacement de volume (albumine), un besoin d'augmenter la capacité de transport de l'oxygène, la correction d'anomalies de l'hémostase, l'amélioration des défenses contre l'infection (granulocytes), et la thérapie immunitaire (globulines immunes variées). Nous présenterons les indications de transfusion de produits sanguins pendant la période périopératoire, en incluant une revue de l'hémostase et des problèmes de coagulation périopératoire, et finalement décrirons les alternatives à la transfusion de produits sanguins.

\section{Capacité de transport de l'oxygène}

Si l'on exclut l'albumine, les produits sanguins ne devraient pas être transfusés initialement pour corriger l'hypovolémie. Des culots globulaires ont remplacé le sang entier lorsqu'il s'agit d'augmenter la capacité de transport de l'oxygène. La règle des « 10/30» (hémoglobine $=10 \mathrm{~g} \cdot \mathrm{dl}^{-1}$ ou hématocrite de $30 \%$ ) n'est plus pertinente chez tous les patients. La livraison d'oxygène dépend autant des systèmes cardio-vasculaire et pulmonaire que de la concentration d'hémoglobine. En condition basale, l'extraction globale d'oxygène est seulement de $25 \%$ (le coeur extrait environ $60 \%$ de l'oxygène livré et a moins de réserve).

Lorsqu'il y a hémodilution isovolémique, plusieurs mécanismes compensatoires sont disponibles pour maintenir une oxygénation tissulaire adéquate. La réduction de viscosité associée à l'hémodilution améliore le débit dans la microcirculation et réduit la post-charge du ventricule gauche. Le débit cardiaque s'améliore par l'augmentation du volume d'éjection et de la fréquence cardiaque de façon variable selon la situation clinique. Pendant l'anesthésie, l'augmentation du volume d'éjection est habituellement le facteur le plus important. ${ }^{15}$ Le débit coronarien augmente de façon proportionnellement plus importante que le débit cardiaque. Le coeur normal va compenser pour des hématocrites réduites jusqu'à 10 à $15 \%{ }^{16,17}$ Cependant les patients avec réserve ventriculaire limitée, maladie valvulaire, hypertrophie ventriculaire ou maladie coronarienne peuvent décompenser à des pourcentages d'hématocrite plus élevés. ${ }^{18-20}$ L'extraction d'oxygène peut augmenter jusqu'à $70 \%$ pendant un exercice maximal mais ceci peut être limité, surtout chez les patients sévèrement malades porteurs de tableau septique et/ou de syndrome de détresse respiratoire de l'adulte. ${ }^{21,22}$ Une augmentation des 2,3 DPG avec déplacement vers la droite de la courbe de dissociation de l'oxyhémoglobine pourra compenser aussi pour l'anémie; ce mécanisme est moins important que l'augmentation du débit cardiaque et de l'extraction de l'oxygène.

Robertie et Gravlee ${ }^{4}$ suggèrent les recommandations suivantes pour les seuils de transfusion dans la période périopératoire :

1 Un seuil d'hémoglobine de $6 \mathrm{gm} \cdot \mathrm{dl}^{-1}$ chez les patients avec anémie chronique compensée, qui ont un point de départ à moins de $8 \mathrm{gm} \cdot \mathrm{dl}^{-1}$, chez les patients en santé qui auront une hémodilution planifiée peropératoire, et chez ceux qui seront soumis à une circulation extracorporelle avec hypothermie.

2 Une hémoglobine de $8 \mathrm{gm} \cdot \mathrm{dl}^{-1}$ devient le seuil minimal préopératoire acceptable pour la chirurgie au cours de laquelle on prévoit perdre plus de $500 \mathrm{ml}$ de sang, pour les patients en phase postopératoire de chirurgie cardiaque, et chez beaucoup de patients ASA 2 ou 3 dans la phase opératoire.

3 Une hémoglobine de $10 \mathrm{gm} \cdot \mathrm{dl}^{-1}$ chez les patients peu susceptibles d'augmenter leur débit cardiaque ou leur débit sanguin régional suffisamment pour compenser le défaut de transport, les patients porteurs de complications postopératoires qui limitent leur réserve cardiaque et augmentent les besoins en oxygène, les gens âgés (plus de 65 ans), et la plupart des patients qui ont besoin de ventilation prolongée (plus de 48 heures).

Il s' agit seulement de recommandations, et les cliniciens doivent ajuster individuellement le traitement. En général la valeur de $7 \mathrm{gm} \cdot \mathrm{dl}^{-1}$ remplace la vieille règle des 10 $\mathrm{gm} \cdot \mathrm{dl}^{-1},{ }^{23-25} \mathrm{chez}$ les patients isovolémiques avec réserve cardio-pulmonaire stable par ailleurs.

\section{L'hémostase}

Une bonne compréhension de l'hémostase va faciliter l'utilisation judicieuse d'épreuves de coagulation et le choix des produits sanguins dans la période périopératoire. L'hémostase implique des composantes vasculaires, cellulaires et humorales avec des mécanismes complexes de rétroaction positive et négative qui permettent des réponses rapides lorsqu'il y a blessure vasculaire localisée. $\mathrm{Au}$ départ, il y a vasoconstriction et formation d'un bouchon plaquettaire; la coagulation amène ensuite 
l'apparition de caillots de fibrines; enfin la fibrinolyse élimine la fibrine.

Les cellules endothélales vasculaires secrètent des prostaglandines, qui sont inhibitrices de l'aggrégation plaquettaires et vasodilatatrices. Un endothélium endommagé expose le collagène sous-endothélial. Le facteur de Von Willebrand, secrété par les cellules endothéliales et les plaquettes, permet l'adhésion des plaquettes circulantes au collagène. Les plaquettes activées relâchent la thromboxane $A_{2}$; celle-ci amène une vasoconstriction locale et aussi la libération d'adénosine diphosphate (ADP) qui favorise l'adhésion plaquettaire, l'aggrégation et la formation du bouchon plaquettaire au site de lésion vasculaire. $L a$ thromboxane $A_{2}$ et les prostacyclines ont des effets opposés sur les vaisseaux et l'ADP; ceci représente la réponse hémostatique localisée.

La phase de coagulation de l'hémostase implique les facteurs de coagulation protéiques du plasma, le calcium et les phospholipides. L'origine du phospholipide détermine le type de cascade (extrinsèque ou intrinsèque) suivi par le processus. Le phospholipide originant de l'extérieur du vaisseau, la thromboplastine tissulaire, est impliqué dans le système intrinsèque; le phospholipide plaquettaire, le facteur plaquettaire III, est requis pour la voie intrinsèque. Cette division est quelque peu artificielle puisqu'il y a des interactions entre les deux voies de formation de fibrine. Cependant, cette interprétation de la cascade de coagulation permet de conceptualiser les anomalies du système et d'interpréter les tests de coagulation courants. La voie extrinsèque est plus rapide que la voie intrinsèque. La thromboplastine tissulaire libérée dans la circulation se lie au facteur VII pour activer le facteur X. L'activation de ce dernier via la voie intrinsèque est plus complexe. L'activation de contact qui implique le facteur XII, le facteur XI, la prékallikréine et le kinogène à haut poids moléculaire initie le processus. Le contact du facteur XII avec une substance à charge négative (collagène, endotoxine, verre, kaolin, etc.) constitue la première étape. Associés avec le kinogène à haut poids moléculaire comme facteur, la prékallikréine et le facteur XI se lient au facteur XI activé (les facteurs activités sont identifiés avec un « a », e.g., XIa). Le facteur XIa scinde le facteur IX en facteur IXa qui forme un complexe sur la surface plaquettaire avec le facteur VIIIa, le calcium et le phospholipide pour activer le facteur $X$.

Le facteur Xa enclenche la voie commune. Le facteur $\mathrm{Xa}$ forme un complexe avec le facteur $\mathrm{Va}$, le calcium, et la prothrombine pour former de la thrombine (la prothrombine scinde le phospholipide). La thrombine, liée au facteur plaquettaire III, scinde le fibrinogène en monomères de fibrine qui s'aggrègent pour former un polymère soluble de fibrine (fibrine S). Le facteur XIII, activé par la thrombine et le calcium, facilite l'association par lien covalent des monomères de fibrine pour former un caillot stable de fibrine insoluble. La thrombine non seulement convertit le fibrinogène en fibrine et active le facteur XIII, mais aussi augmente l'activité des co-facteurs V et VIII, fait démarrer la fibrinolyse et entretient l'aggrégation plaquettaire.

Il faut se rappeler que les facteurs dépendants de la vitamine $\mathrm{K}$ (II, VII, IX, X) sont impliqués dans les voies extrinsèque, intrinsèque et commune. Comme le facteur VII a la demi-vie la plus courte, un déficit en vitamine $K$, une maladie hépatique et la thérapie à la warfarine vont d'abord toucher la voie extrinsèque comme nous le montre le temps de prothrombine élevé.

La prévention d'une coagulation intravasculaire massive non contrôlée s'accomplit par plusieurs mécanismes. Tel que noté, la prostacycline de l'endothélium vasculaire normal entretient la vasodilatation, empêche l'aggrégation plaquettaire et l'exposition au facteur plaquettaire III. Le débit sanguin normal dilue et lave les facteurs de coagulation activés qui sont extraits de façon préférentielle de la circulation. L'antithrombine III, la protéine $C$ et la protéine $S$ sont des anticoagulants naturels. L'anti-thrombine III se combine à la thrombine et aux facteurs IXa, Xa, XIa et XIIa, et les élimine de la circulation. L'héparine augmente la liaison de l'anti-thrombine III d'au moins 100 fois. La protéine $C$ dont l'activation est augmentée par la protéine $S$, assure la dégradation des facteurs Va et VIIIa et facilite la fibrinolyse. La fibrinolyse se produit habituellement d'une façon contrôlée. Lorsque le danger d'hémorragie est passé, le bouchon de fibrine doit être modifié pour ramener la circulation normale dans le vaisseau. Le plasminogène se lie à la fibrine à l'intérieur du caillot et lorsqu'activé par l'activateur de plasminogène tissulaire, la plasmine obtenue assure la lyse de caillot par l'intérieur. L'antiplasmine circulante neutralise la plasmine libre. La plasmine scinde le fibrinogène, la fibrine liée et non liée, ce qui amène la libération de produits de dégradation de la fibrine, qui à leur tour, peuvent inhiber la coagulation et la fonction plaquettaire.

\section{Évaluation de routine de l'hémostase}

L'histoire et l'examen physique peuvent orienter vers une évaluation des mécanismes de l'hémostase par un certain nombre d'épreuves. Un décompte plaquettaires de plus de 150000 plaquettes par $\mu^{-1}$ est considéré comme normal. L'épreuve perd de sa précision en dessous de 20000 plaquettes par $\mathrm{\mu l}^{-1}$. Le temps de saignement normal est de moins de 10 minutes et est un indicateur de la fonction plaquettaire lorsque celles-ci ont un décompte 100000 $\mu \mathrm{l}^{-1}$, puisqu' il augmente de façon linéaire à mesure que les décomptes passent de 100000 à 10000 plaquettes par $\mu \mathrm{I}^{-1}$. Le temps de saignement sera aussi allongé par un facteur de Von Willebrand déficitaire ou anormal, une 
hypofibrigénémie sévère et une anémie sévère. ${ }^{26}$ Le temps de prothrombine (PT) et le temps de thromboplastine partielle (PTT) sont les épreuves classiques d'évaluation des cascades intrinsèque (PT) et intrinsèque (PTT), respectivement. Il faut comprendre que ces épreuves demeureront dans les limites normales, à moins que les niveaux de facteurs soient inférieurs à $30 \%$, que l'on évaluera aussi la voie commune par ces épreuves, et puisque ces épreuves évaluent finalement la formation de caillots de fibrine, le facteur XIII n'est pas évalué. Un prolongement du PTT, non corrigé par mélange à $50 / 50$ de plasma normal, pourra être causé par des inhibiteurs des facteurs de coagulation et représente un problème plus complexe à manipuler qu' une simple déficience de facteur. Le temps de thrombine est prolongé par l'héparine alors que le temps de la reptilase ne l'est pas. Les deux sont prolongés par les anomalies du fibrinogène et les produits de dégradation de la fibrine.

Rapaport ${ }^{27}$ a suggéré certaines recommandations pour l'évaluation préopératoire en stratifiant les patients par niveau de risque selon leur histoire de saignement et la chirurgie envisagée. Les patients du niveau I ont une histoire négative de saignement, doivent subir des chirurgies mineures, et aucune évaluation de la coagulation n'est recommandée. Le niveau II comprend des patients avec une histoire négative de saignement, mais qui subissent une chirurgie majeure. Un décompte plaquettaire et un temps de thromboplastine partiel (PTT) devrait faire partie de l'évaluation. Les patients du niveau III ont une histoire suggérant des troubles de saignement et comprennent aussi les patients dont la chirurgie est exigeante pour le système hémostatique, e.g., circulation extra-corporelle, chirurgie prostatique, ou chirurgie avec tolérance faible pour le saignement (neurochirurgie). Il faut pousser ici l'évaluation et mesurer le temps de prothrombine, le temps de thromboplastine partiel, le décompte plaquettaire, et possiblement le temps de saignement et la fibrinolyse. Les patients du niveau IV ont une histoire de saignement important et peuvent nécessiter en plus des épreuves mentionnées ci-haut, des évaluations de facteurs spécifiques, l'évaluation de l'aggrégation plaquettaire, du temps de prothrombine, etc. Il faut consulter un hématologiste dans les cas compliqués.

\section{Anomalies courantes de l'hémostase pendant la période périopératoire}

\section{Congénitales}

Les désordres les plus courants sont la maladie de Von Willebrand et l'hémophillie A et B; le facteur de Von Willebrand eșt nécessaire pour l'adésivité plaquettaire et comme transporteur du facteur VIII. La maladie de Von Willebrand est classifiée en types I, II-A, B, C, D, III, et de type plaquettaire. Le type I, le plus courant, est transmis par gène dominant. Ces patients seront préparés de façon sécuritaire pour la chirurgie en leur donnant de la 1-déamino-8-D-arginine vasopressine (DDAVP) à 0,3 $\mu \mathrm{g} \cdot \mathrm{kg}^{-1}$ par voie intraveineuse, une heure avant l'opération. On documente ensuite la correction du temps de saignement et/ou l'élévation suffisante du facteur VIII, 45 minutes après l'administration de DDAVP, qui sera répétée tous les jours jusqu'à ce que la cicatrisation soit complète. Les types II et III nécessiteront l'utilisation de cryoprécipité à raison de 2 unités par $10 \mathrm{~kg}$ à toutes les 12 heures, débutant une heure avant l'intervention et se continuant jusqu'à ce que la cicatrisation soit complétée.

Les hémophilies A et $B$ sont des déficiences du facteur VIII et IX liées aux sexe et qui touchent surtout les mâles. La préparation pour la chirurgie dans l'hémophilie A nécessite l'élévation du facteur VIII jusqu'à 80 à $100 \%$ des niveaux normaux. Une unité de facteur VIII par $\mathrm{kg}$ élève le niveau plasmatique de $2 \%$. Le cryoprécipité contient environ 100 unités de facteur VIII par $10 \mathrm{ml}$. Un concentré de facteur VIII lyophilisé est aussi disponible: son activité est inscrite sur l'étiquette. Ce concentré est utile dans l'hémophilie A mais pas pour la maladie de Von Willebrand. De 40 à 50 unités par $\mathrm{kg}$, une heure avant la chirurgie, élèveront les niveaux de facteur VIII jusqu'à 80-100\% de la normale pour la chirurgie et 15 à 25 unités par $\mathrm{kg}$ à toutes les 12 heures pour 10 à 14 jours conserveront l'activité du facteur VIII aux environs de 30 à $50 \%$ pendant la période postopératoire. Dans la chirurgie dentaire, un gramme d'acide epsilon amino caproïque donné par voie orale à toutes les 4 heures pendant 7 à 10 jours constitue la thérapie antifibrinolytique. Une hémophilie A modérée répondra adéquatement au DDAVP donné une heure avant l'intervention et à toutes les 12 heures en postopératoire, avec surveillance fréquente du facteur VIII.

Dans l'hémophilie B une unité de Facteur IX $\cdot \mathrm{kg}^{-1}$ augmentera le niveau de facteur IX plasmatique de $1 \%$. Le complexe de facteur IX, qui contient d'autres facteurs activés, comporte certains risques de thrombose, et certains patients sont mis sous thérapie prophylactique à l'héparine sous-cutanée à faible dose.

\section{Désordre acquis de l'hémostase}

Les anomalies de nombre et de fonction plaquettaire sont très courantes. Un décompte plaquettaire à la baisse est le résultat de production diminuée, de consommation augmentée, de destruction ou de séquestration, et la conduite va varier selon l'étiologie. De façon générale, le saignement chirurgical n'augmente pas à moins que le décompte plaquettaire soit inférieur à $50000-100000$ plaquettes $\cdot \mu \mathrm{I}^{-1}$. Un saignement spontané peut se produire à des niveaux inférieurs à 20000 plaquettes $\cdot \mu l^{-1}$. Les 
anomalies acquises de fonction plaquettaire sont courantes, et l'aspirine cause le plus d'inquiétudes. Elle touche l'aggrégation plaquettaire par le biais d'une inhibition de la synthèse de la thromboxane $A_{2}$ et cette anomalie perdure pendant toute la vie des plaquettes touchées (10 jours). Le DDAVP peut contrecarrer une partie de cet effe $^{28}$ et deux unités de plaquettes devraient libérer suffisamment d'ADP pour faciliter l'aggrégation des plaquettes touchées. Le temps de saignement a été critiqué comme prédicteur du risque de saignement ${ }^{29}$ et les résultats des études sur le saignement augmenté des patients chirurgicaux qui prennent de l'aspirine sont controversés. Cependant, il faut se méfier des effets additionnels d'autres coagulopathies chez les patients porteurs de dysfonction plaquettaire. Les anomalies plaquettaires de l'urémie ne sont pas corrigées par la transfusion de plaquettes mais répondent à la dialyse et au DDAVP. La correction d'une anémie sévère peut aider ${ }^{26}$, ainsi que le cryoprécipite ${ }^{30}$, à raccourcir le temps de saignement dans l'urémie.

La coagulopathie de la maladie hépatique provient de plusieurs facteurs : diminution du décompte plaquettaire par baisse de production, séquestration dans la rate ou consommation dans la coagulation intravasculaire disséminée, diminution de la fonction plaquettaire secondaire à l'alcool ou aux produits de dégradation de la fibrine, et diminution de facteurs de coagulation incluant le fibrinogène ou encore production de fibrinogène anormal. La coagulation intravasculaire disséminée peut se produire dans la maladie du foie et être aussi une complication des dérivations péritonéoveineuses pour contrôle de l'ascite. Des plaquettes, du plasma congelé et du cryoprécipité pourront être nécessaires dans des situations de saignement sévère. La vitamine $\mathrm{K}$ peut être efficace même dans les situations de dysfonction hépatique sévère, et il y a certains travaux qui suggèrent que le DDAVP pourrait raccourcir le temps de saignement. ${ }^{28}$

Les patients sous Warfarine qui ont besoin de chirurgie immédiate nécessiteront une transfusion de plasma décongelé ainsi que d'une thérapie à la vitamine $\mathrm{K}$. La vitamine $\mathrm{K}$ commencera à corriger le déficit de coagulation en 4 à 6 heures, mais demandera beaucoup plus de temps pour un recouvrement complet et rendra le rétablissement subséquent de l'anticoagulation difficile. Le déficit de vitamine $\mathrm{K}$ par malnutrition ou thérapie aux antibiotiques est courant chez les patients hospitalisés et devrait être soupçonné chez les patients avec un temps de prothrombine élevé retrouvé dans les épreuves de routine.

Les patients avec transfusion massive (recevant plus que leur volume sanguin en 24 heures ou moins) demandent une attention spéciale. La coagulopathie associée est habituellement une thrombocytopénie dilutionnelle, mais il peut aussi y avoir augmentation de consommation et de destruction plaquettaires, ainsi qu'une diminution des niveaux de facteurs labiles $V$ et VIII dans certaines situations et finalement une hypofibrinogénémie si la coagulation intra-vasculaire disséminée fait partie du tableau clinique. Même si l'on déconseille la transfusion prophylactique de plaquettes, de plasma décongelé et de cryoprécipité en chirurgie cardiaque et chez les patients subissants des transfusions massives, ${ }^{31,32}$ on peut à l'occasion utiliser son flair clinique puisque les épreuves courantes de laboratoire peuvent ne pas être disponibles rapidement en salle d'opération. La thromboélastographie peut aider dans le diagnostic de telles coagulopathies intraopératoires et faciliter la thérapie. ${ }^{33}$ Puisque l'anémie sévère peut toucher la fonction plaquettaire, la transfusion de globules rouges devient importante et ce au-delà du besoin de transport de l'oxygène chez ces patients.

\section{Alternatives à la transfusion de sang homologue}

Au delà de l'acceptation d'une hématocrite plus faible avant de transfuser, il y a plusieurs options qui permettent de diminuer la transfusion de sang homologue. ${ }^{34}$

L'hypotension contrôlée, même si elle demeure controversée, diminue les pertes sanguines pendant la chirurgie, et si elle est bien administrée chez certains patients, elle est sécuritaire. ${ }^{4}$ Rappelons nous aussi qu'une diminution de pression artérielle et non pas du débit cardiaque, est désirable lorsque combinée avec une hémodilution modérée. Une réduction de $30 \%$ de pression artérielle moyenne avec limite inférieure fixée à $50 \mathrm{mmHg}$ demeure sécuritaire.

L'hémodilution aiguë avant ou pendant la chirurgie jusqu'à une hématocrite de $24 \%$ amènera une diminution de la perte d'hémoglobine et, on l'espère, une diminution des besoins de transfusion. Ceci peut être accompli en prélevant du sang d'un patient qui sera retransfusé plus tard ou simplement en amenant une vasodilatation chez le patient et en infusant des crystalloïdes ou des colloïdes pour atteindre un niveau déterminé d'hématocrite. Puisque le diurèse peut être nécessaire, la fonction rénale devrait être adéquate et il faut suivre l'hématocrite de façon attentive.

La mise en réserve de sang autologue avant la chirurgie $^{35}$ est sous utilisée et devrait être proposé à certains patients à haut risques. ${ }^{36}$ Cependant le risque de surcharge volémique, la contamination et les erreurs cléricales conduisant à l'incompatibilité sont toujours possibles, et si un patient qui a fait un don préopératoire n'a pas à être transfusé, on devrait éviter de lui redonner son sang. ${ }^{37} \mathrm{Le}$ traitement préopératoire avec érythropoïétine peut augmenter le volume de globules rouges obtenus avant l'intervention. ${ }^{38}$

La récupération du sang pendant les interventions est surtout utile dans les interventions à pertes importantes de 
sang telles les chirurgies cardiovasculaire, orthopédique, post-traumatique ou lors de la transplantation de foie. Les contrindications relatives comprennent l'infection et les néoplasies. Actuellement seuls les globules sont récupérés mais ceci pourra changer éventuellement. ${ }^{39}$

Les agents pharmacologiques peuvent réduire les pertes sanguines dans quelques situations. ${ }^{28}$ La DDAVP et la vitamine $\mathrm{K}$ ont été mentionnées plus tôt; les résultats avec la DDAVP en chirurgie cardiaque sont controversés et actuellement on ne recommande pas cette thérapie de routine dans ce contexte. Les antifibrinolytiques (l'acide epsilon amino caproïde, l'acide tranexamique) ont diminué les saignements en chirurgie orale, la chirurgie de la prostate et la chirurgie cardiaque, sans augmentation apparente du risque de thrombose. ${ }^{4,40} \mathrm{~L}$ 'aprotinine, une sérine inhibitrice de la protéase, de la plasmine et de la kallikréine et qui protège les membranes plaquettaires pendant la circulation extra-corporelle, semble diminuer les pertes sanguines dans la chirurgie cardiaque. ${ }^{4,41,42}$

Les substituts sanguins, perfluorocarbone et hémoglobines polymérisées, sont toujours des sujets de recherche et ne sont pas maintenant disponibles pour usage clinique.

\section{Résumé}

Un seuil d'hémoglobine plus bas en prétransfusion, une meilleure compréhension de l'hémostase et la connaissance d'alternatives à la transfusion homologue devraient rendre la pratique de la transfusion sanguine plus rationnelle.

\section{Références}

(Voir page R106) 